\title{
Control of bacterioplankton growth and abundance in deep, oligotrophic Loch Ness (Scotland)
}

\author{
Roger I. Jones*, Judith M. Young \\ Department of Biological Sciences, Institute of Environmental and Natural Sciences, Lancaster University, \\ Lancaster LA1 4 YQ, United Kingdom
}

\begin{abstract}
Control of bacterial growth and abundance in the plankton of Loch Ness, a deep, oligotrophic lake in northern Scotland, UK, was studied over a 12 mo period. Bacterial intrinsic growth rates and grazing loss rates were estimated from dilution experiments. Growth limitation due to resource availability was determined from nutrient addition experiments. Measured bacterial intrinsic growth rates ranged from zero to $0.69 \mathrm{~d}^{-1}$, these low growth rates being typical of oligotrophic lakes. Bacterial growth rate was stimulated on different occasions by addition of an organic carbon substrate or by addition of mineral nutrients; however, during summer stratification bacterial growth was principally limited by phosphorus availability. Bacterial growth rate fluctuated irregularly, apparently influenced by the influx of resources from the catchment and hence by rainfall patterns. Bacterial growth rarely responded to increased incubation temperature. Although bacterial growth in Loch Ness was generally slow, new bacterial production was removed quite efficiently by grazers and bacterial densities showed only little fluctuation. Heterotrophic nanoflagellates were sometimes an important component of the bacterivore commun:ty, but other grazers such as cladocerans also appeared to play an important role in Loch Ness.
\end{abstract}

KEY WORDS: Bacterial growth $\cdot$ Bacterivory $\cdot$ Nutrients Temperature $\cdot$ Loch Ness

\section{INTRODUCTION}

It is now well established that heterotrophic bacteria play a key role in pelagic food webs in marine and freshwater ecosystems (Pomeroy 1974, Azam et al. 1983). A rapidly expanding literature contains reports that bacteria can account for a large part of the flux of carbon through pelagic systems in lakes (Cole et al. 1988). In productive lakes, and in unproductive clearwater lakes, bacterioplankton are assumed to rely on autochthonous carbon fixed by phytoplankton. By contrast, in unproductive lakes which receive substantial inputs of allochthonous organic carbon, bacteria can provide a critical link whereby some of this carbon is channelled up the food chain (Jones 1992). Thus in some systems much of the bacterial production appar-

\footnotetext{
•E-mail: r.jones@lancaster.ac.uk
}

ently moves up to higher trophic levels. However, there is still considerable debate as to whether this is always the case or whether bacterial production is often largely respired within the several components of a microbial food web (Ducklow et al. 1986, Weisse 1990). A better knowledge of the factors which control bacterial abundance and production is therefore central to understanding planktonic food webs in lakes.

One widely accepted general observation is that populations of planktonic bacteria show limited variation in abundance, either between lakes or through time within a single lake, with reported densities usually in the region of $10^{6}$ cells $\mathrm{ml}^{-1}$ (Azam et al. 1983, Pace 1988). This apparent low variability clearly implies that bacterioplankton production must be rapidly and effectively exploited so that net population change is minimal. In marine pelagic systems, heterotrophic nanoflagellates (HNF) are considered to be the principal bacterivores (Fenchel 1982a, Sieburth \& 
Davis 1982). Although lakes contain a wider variety of zooplankton that may utilise bacteria effectively, including ciliates, rotifers and crustaceans (Borsheim 1984, Kankaala 1988, Sanders et al. 1989), HNF are still usually presumed to be the dominant bacterivores, particularly in oligo- and mesotrophic lakes (Güde 1986, Weisse 1990, Berninger et al. 1991).

The relatively constant bacterioplankton abundance arises despite the fact that bacterial growth and production in lakes can be high and can show considerable variability (Billen et al. 1990). Thus it is possible that the same bacterial abundance could arise when a population is (1) growing rapidly but being grazed rapidly or (2) growing only slowly but suffering little grazing loss. In the first case it might be assumed that the bacterial growth is not restricted by any essential resource (organic carbon substrate, mineral nutrients, temperature) and that the population is controlled primarily by the action of grazers. In the second case the slow growth rate would indicate that the population was controlled primarily by a shortage of one or more resources. In current terminology these 2 cases would be referred to respectively as 'top-down' and 'bottomup' control (McQueen et al. 1986, Pace \& Cole 1994). Although some authors (e.g. Berninger et al. 1991, Sanders et al. 1992) have argued the importance of top-down control, particularly in more eutrophic systems, comparative studies generally point to the importance of bottom-up regulation of bacteria (Billen et al. 1990, Pace \& Cole 1994). In fact the 2 possible control mechanisms are not mutually exclusive, and it is quite possible that their relative importance in regulating bacteria might vary seasonally (Ducklow et al. 1992, Sanders et al. 1992). The same is true of the particular resource that might be most limiting to bacterial growth in lakes. Early marine studies led to a widespread view that bacterioplankton growth rates are limited by the release of dissolved organic carbon (DOC) from phytoplankton, and correlations between bacterial production and phytoplankton biomass or production (Bird \& Kalff 1984, Marvalin et al. 1989, Robarts \& Wicks 1990) suggested that the same might be true in lakes. However, other studies have shown that bacterioplankton effectively compete with phytoplankton for inorganic nutrients in both oligotrophic and eutrophic lakes (Currie \& Kalff 1984a, b, Vadstein et al. 1988), indicating that inorganic nutrients might be as important as DOC in regulating bacterial growth rates. Attempts to resolve this argument by studying the response of bacterial growth to enrichment with DOC or inorganic nutrients have been inconclusive, with either resource or both together being required to stimulate growth during different experiments (Toolan et al. 1991, Coveney \& Wetzel 1992, Wang et al. 1992, Bell et al. 1993, Elser et al. 1995).

In fact there is good reason to suppose that the resource with most influence on bacterial growth might vary seasonally and between lakes, depending on the magnitude of phytoplankton production, inputs of allochthonous DOC and the availability of inorganic nutrients. However, there are few systematic studies of seasonal variation in the factors controlling bacterioplankton growth and abundance in lakes. Here, we present results from a 12 mo study of top-down and bottom-up influences on bacteria in the plankton of a deep, oligotrophic lake with appreciable inputs of allochthonous organic carbon.

\section{METHODS}

Experiments were conducted using water samples from Loch Ness. This is the largest volume of water in the British Isles and occupies a simple trench-like basin $39 \mathrm{~km}$ long and $1.5 \mathrm{~km}$ wide (Maitland 1981). The loch has a maximum depth of $230 \mathrm{~m}$ and a mean depth of $132 \mathrm{~m}$. The loch is never ice-covered and is warm monomictic, although the strong winds which frequently blow up the long axis mean that even during summer stratification the depth of mixing extends to $30-40 \mathrm{~m}$. Some summary data on conditions in Loch Ness are given in Table 1.

Between February 1996 and January 1997 samples were collected at approximately monthly intervals from a mid-loch station located over a depth of $200 \mathrm{~m}$ A $30 \mathrm{~m}$ flexible tube was used to collect several integrated samples from the $0-30 \mathrm{~m}$ water column which were mixed in a clean bucket after straining through a $110 \mu \mathrm{m}$ mesh to remove large crustacean zooplankton. The mixed sample was used to fill 2 l polypropylene bottles which had been acid washed, rinsed with Milli$Q$ water and autoclaved. The samples were returned to the laboratory in an insulated box. The water temperature at the time of sampling was measured with a YSI

Table 1. Representative values for some physical and chemical characteristics of Loch Ness

\begin{tabular}{|c|c|c|}
\hline Volume $\left(10^{9} \mathrm{~m}^{3}\right)$ & 7.45 & (Maitland 1981) \\
\hline Water residence time (yr) & 2.81 & (Maitland 1981) \\
\hline Surface temperature range $\left({ }^{\circ} \mathrm{C}\right)$ & $6-13$ & (This study) \\
\hline Water colour (mg Pt l-1) & 50 & (Jones unpubl.) \\
\hline $\mathrm{DOC}\left(\mathrm{mg} \mathrm{l}^{-1}\right)$ & $3-5$ & (Jones et al. 1997) \\
\hline Total phosphorus ( $\left.\mathrm{Hg} \mathrm{l}^{-1}\right)$ & 10 & (Jones unpubl.) \\
\hline Soluble reactive phosphate $\left(\mu \mathrm{g} \mathrm{I}^{-1}\right)$ & 5 & (Jones unpubl.) \\
\hline Inorganic nitrogen ( $\mu \mathrm{l}^{1}$ ) & 100 & (Maitland 1981) \\
\hline Maximum chlorophyll a ( $\mu \mathrm{g} \mid \mathrm{l}$ ) & 1.5 & (Jones et al. 1996) \\
\hline
\end{tabular}


probe and meter. Oxygen measurements were not taken, but previous studies (Maitland 1981, LaybournParry et al. 1994) have shown that the entire water column in Loch Ness is always close to $100 \%$ saturated with oxygen.

Estimates of the rate of bacterivory and of the intrinsic (gross) growth rate of bacteria were made using a dilution technique (Landry \& Hassett 1982). All glassware was acid washed, rinsed with Milli-Q water and autoclaved. Sample water was filtered through $0.2 \mathrm{~km}$ pore size Anodisc inorganic filters. The filtrate was then mixed with unfiltered sample in the following ratios of unfiltered sample water to $0.2 \mu \mathrm{m}$ filtrate: 1.0 , $0.8,0.6,0.4$ and 0.2 . The mixtures were incubated for $5 \mathrm{~d}$ in triplicate in $100 \mathrm{ml}$ glass bottles in the dark in a water bath set to the temperature of the loch at the time of sampling. Bottles were not shaken during the incubation, but agitation has been shown to have no impact on microbial behaviour (Tranvik 1989). Apparent growth rates (AGR) at each dilution were estimated from the change in bacterial density between Day 0 and Day 5. Preliminary trials showed that exponential growth of bacteria in unenriched Loch Ness water samples lasted for around 7 d. Five day incubations were used to maximise changes in bacterial densities while ensuring growth remained within the exponential phase. The intrinsic (gross) growth rate $(\mu)$ and grazing loss rate $(g)$ were obtained by linear regression of AGR versus the fraction of undiluted sample $(d)$ :

$$
\mathrm{AGR}=\mu-g d
$$

Possible resource limitation of bacterial growth was also investigated on each occasion by nutrient enrichment experiments. All glassware was acid washed, rinsed with Milli- $Q$ water and autoclaved. Sample water was filtered through $1 \mathrm{\mu m}$ pore size track-etched polycarbonate (TEPC) filters to screen out most grazers but retain most bacteria. The filtered water was dispensed to $100 \mathrm{ml}$ glass bottles to which nutrient additions were made as follows: no addition (control); $500 \mu \mathrm{g} \mathrm{l}^{-1}$ carbon as glucose (C); $10 \mu \mathrm{g} \mathrm{PO}_{4}-\mathrm{P} \mathrm{I}^{-1}$ (P); $70 \mu \mathrm{g} \mathrm{NH}_{4}-\mathrm{N} \mathrm{l}^{-1}(\mathrm{~N})$; and a combined nutrient addition (CNP) with each nutrient added at the same concentration as in the single nutrient treatments. The bottles were incubated $(6 \mathrm{~d})$ in the dark in a water bath set to the temperature of the loch at the time of sampling. A separate sample with no added nutrients was incubated at $16^{\circ} \mathrm{C}$ approximating the annual maximum temperature attained in Loch Ness (Jones et al. 1996). All treatments were performed in triplicate. Samples from each bottle were removed at 0,4 and $6 \mathrm{~d}$ for bacterial counting and a regression of $\ln$ (bacterial density) against time was used to estimate the growth rate. Differences in growth rates between treatments and the control were assessed by t-test following log transformation of the data to normalise the distribution.

Bacteria were counted by staining and epifluorescence microscopy (Kepner \& Pratt 1994). Samples were preserved with buffered glutaraldehyde (final concentration $2 \%$ ). An appropriate aliquot $(0.1$ to $10 \mathrm{ml}$ according to the bacterial density) was filtered onto a $25 \mathrm{~mm}$ black $0.2 \mu \mathrm{m}$ TEPC filter mounted on a $0.45 \mu \mathrm{m}$ cellulose acetate backing filter and stained with DAPI for $7 \mathrm{~min}$ at a final concentration of $0.1 \mu \mathrm{g} \mathrm{l^{-1 }}$. Small aliquots were diluted to $2 \mathrm{ml}$ with autoclaved Milli-Q water to ensure even distribution of bacteria on the filter membrane. The filter was then sucked dry and mounted on a slide with Cargille type A non-fluorescing immersion oil and bacteria were counted at $\times 1250$ magnification using a Leitz Laborlux epifluorescent microscope with UV excitation. A minimum of 400 cells in at least 5 fields of view were counted. Densities of heterotrophic flagellates in the original samples were also determined using epifluorescent microscopy, but with the primulin staining technique of Caron (1983). Flagellates were considered heterotrophic if they failed to autofluoresce under blue or green light excitation.

\section{RESULTS}

Dilution experiments to determine both bacterial intrinsic growth rates and rates of grazing loss were carried out at approximately monthly intervals between February 1996 and January 1997. Examples of 2 of the resultant graphical plots, for February and July

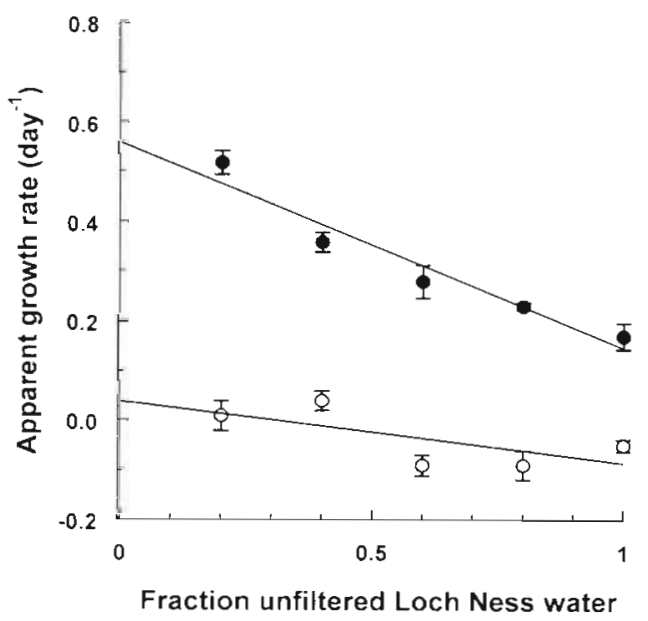

Fig. 1. Examples from February 1996 (O) and July 1996 (•) of results from dilution experiments using Loch Ness water. Data points are means of 3 replicates and vertical bars show standard errors. The fitted regression lines for each occasion are: February, $y=0.039-0.125 x(r=0.670)$; July, $y=0.561-$ $0.415 \times(r=0.968)$ 
Table 2. Seasonal changes in Loch Ness samples during 1996/97 of bacterial intrinsic growth rate and grazing loss rate obtained from dilution experiments together with the correlation coefficient (r) from the fitted regression. Also shown. are the initial abundances on each occasion of bacteria and heterotrophic nanoflagellates, as well as the mean $0-30 \mathrm{~m}$ temperature in the loch at the time of sampling and whether the water column was stratified. Where appropriate, mean values are shown \pm standard errors

\begin{tabular}{|c|c|c|c|c|c|c|c|}
\hline & $\begin{array}{c}\text { Intrinsic } \\
\text { growth rate } \\
\left(d^{-1}\right)\end{array}$ & $\begin{array}{l}\text { Grazing rate } \\
\qquad\left(\mathrm{d}^{-1}\right)\end{array}$ & r & $\begin{array}{c}\text { Bacterial } \\
\text { abundance } \\
\left(10^{5} \text { cells } \mathrm{ml}^{-1}\right)\end{array}$ & $\begin{array}{c}\text { HNF } \\
\text { abundance } \\
\left(10^{2} \text { cells } \mathrm{ml}^{-1}\right)\end{array}$ & $\begin{array}{c}\text { Temperature } \\
\left({ }^{\circ} \mathrm{C}\right)\end{array}$ & $\begin{array}{l}\text { Stratified } \\
\text { water } \\
\text { column }\end{array}$ \\
\hline February & $0.039 \pm 0.053$ & $0.125 \pm 0.080$ & 0.670 & $3.88 \pm 0.25$ & $2.60 \pm 0.12$ & 6 & No \\
\hline March & $-0.037 \pm 0.056$ & $-0.045 \pm 0.084$ & 0.293 & $2.26 \pm 0.27$ & $2.19 \pm 0.26$ & 6 & No \\
\hline April & $0.228 \pm 0.043$ & $0.220 \pm 0.066$ & 0.888 & $2.45 \pm 0.11$ & $0.88 \pm 0.10$ & 8 & No \\
\hline May & $0.637 \pm 0.030$ & $0.505 \pm 0.046$ & 0.988 & $4.03 \pm 0.63$ & $1.04 \pm 0.12$ & 8 & No \\
\hline July & $0.561 \pm 0.041$ & $0.415 \pm 0.062$ & 0.968 & $9.91 \pm 0.34$ & 0 & 10 & Yes \\
\hline August & $0.389 \pm 0.080$ & $0.125 \pm 0.121$ & 0.513 & $3.15 \pm 0.48$ & 0 & 12 & Yes \\
\hline September & $0.324 \pm 0.048$ & $0.030 \pm 0.072$ & 0.235 & $10.12 \pm 1.00$ & $0.98 \pm 0.19$ & 13 & Yes \\
\hline October & $0.547 \pm 0.036$ & $0.545 \pm 0.055$ & 0.985 & $8.07 \pm 0.23$ & $2.05 \pm 0.48$ & 12 & Yes \\
\hline November & $0.670 \pm 0.045$ & $0.370 \pm 0.068$ & 0.953 & $4.32 \pm 0.19$ & $0.87 \pm 0.16$ & 8 & No \\
\hline January & $0.687 \pm 0.077$ & $0.445 \pm 0.116$ & 0.911 & $6.00 \pm 0.37$ & 0 & 6 & No \\
\hline
\end{tabular}

1996, are shown in Fig. 1. In February, the intrinsic growth rate ( $y$-intercept) was extremely low and the grazing rate (slope of line) was also lowi in July growth and grazing rates were higher. The monthly data for growth and grazing rates, together with the initial densities of bacteria and HNF, are summarised in Table 2. In general the dilution experiments generated data which were explained well by the fitted regressions, although in 2 experiments (March and September 1996) the fit was very poor.

At the start of the study, the measured intrinsic growth rate of Loch Ness bacterioplankton was

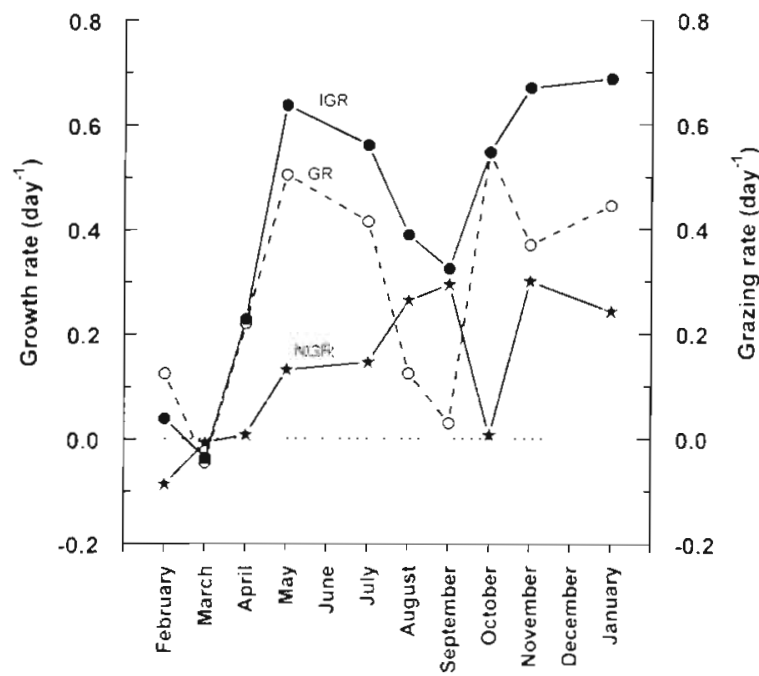

Fig. 2. Seasonal variation during 1996/97 in Loch Ness of bacteria] intrinsic (gross) growth rate (IGR, $\bullet$ ) and grazing loss rate $(G \mathrm{R}, 0$ ) estimated from monthly dilution experiments. Also shown is the estimate of bacterial net growth rate (NGR $\star$ ), the difference between gross growth rate and grazing loss rate extremely low (Fig. 2), but through the spring of 1996 the rate increased progressively before declining during summer. In the autumn, the intrinsic growth rate increased again and actually reached the highest recorded value of $0.687 \mathrm{~d}^{-1}$ in January 1997. The estimated rate of grazing loss of bacteria (Fig. 2) showed a similar pattern to that for the bacterial intrinsic growth rate. However, grazing rate only rarely equalled or exceeded the bacterial intrinsic growth rate, so that the estimated net growth rate of bacteria was generally positive (Fig. 2), in which case some net increase in bacterial density should have been possible. In fact, during the early part of the study, when bacterial net growth rate was negative or zero, there was no observed increase in bacterial density (Fig. 3). Bacter-

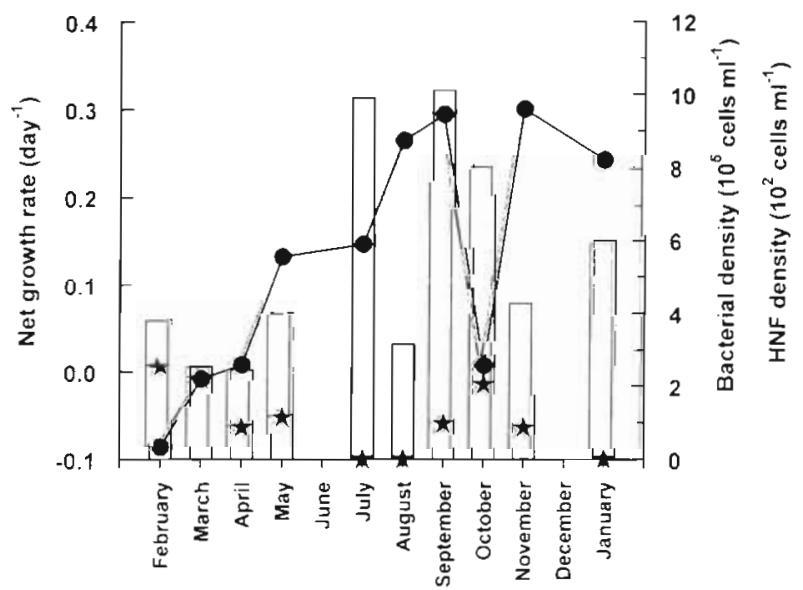

Fig. 3. Seasonal variation during $1996 / 97$ of densities of bacteria (open bars) and heterotrophic nanoflagellates (HNF, $\star$ ) in water samples coliected from Loch Ness. Also shown are the estimates of bacterial net growth rate (-) obtained from dilution experiments 

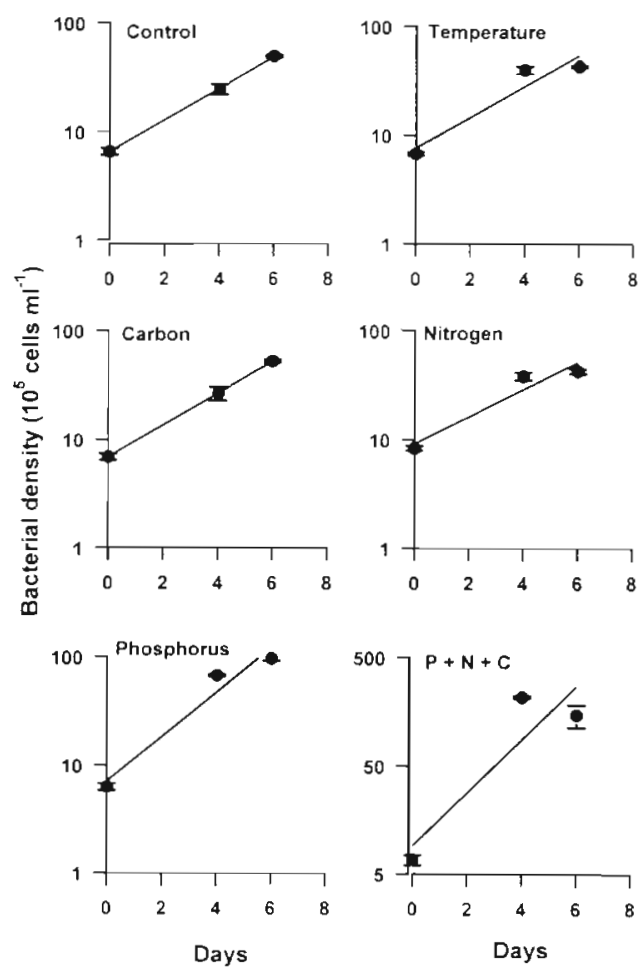

Fig. 4. An example from July 1996 of the changes in bacterial density in water samples from Loch Ness (prefiltered through $1 \mu \mathrm{m}$ pore size filters) following manipulation of temperature or addition of nutrients. Data points are means of 3 replicates and vertical bars show standard errors. See text for further details

ial density did increase later in the year when the net growth rate increased. The density of HNF (Table 2, Fig. 3) fluctuated through the study period, with only trace densities (insufficient for counting) during summer 1996 and again in January 1997.

The intrinsic growth rate of bacterioplankton is presumably determined mainly by environmental conditions: the availability of an organic carbon substrate, the availability of essential mineral nutrients and the ambient temperature. Bacterial response to these factors was determined by incubations of water samples (filtered through $1 \mu \mathrm{m}$ filters to remove grazers) supplemented with additions of glucose, phosphorus or nitrogen, or with the temperature increased from that measured at the time of sampling to $16^{\circ} \mathrm{C}$, approximating the maximum seasonal temperature attained in Lach Ness. An example of the growth responses observed (from July 1996) is shown in Fig. 4.

The effect of different treatments on the bacterial growth rate relative to that of the control (no nutrient addition, ambient loch temperature) is summarised in Table 3 . It is clear that no single factor was controlling bacterial growth rate throughout the study; additions of phosphorus, nitrogen and glucose individually all stimulated bacterial growth on at least 1 occasion. Additions of nitrogen or glucose alone occasionally stimulated bacterial growth, but not with any recognisable seasonal pattern. However, bacterial growth was consistently stimulated by addition of phosphorus alone during the summer stratified period in the loch. Addition of all 3 nutrients together stimulated growth throughout the summer (May to October), and the stimulation of growth from addition of all 3 nutrients was always significantly greater than that obtained from addition of any one nutrient on its own.

On 2 occasions (May and September), incubations at the seasonal maximum loch temperature produced a statistically significant, but only minor, increase in bacterial growth rate (Table 3 ). These apparent temperature effects all occurred when the ambient loch temperature was not much below the seasonal maximum; during the winter months, when the loch temperature was lowest (around $6^{\circ} \mathrm{C}$ ), incubation at the higher temperature never produced any stimulation of bacterial growth rate. Indeed, in November a significantly lower growth rate was measured at the higher incubation temperature. This surprising apparent lack of a consistent response of growth rate to temperature was investigated further in February 1997 when the loch temperature was again $6^{\circ} \mathrm{C}$. Water samples (filtered through $1 \mu \mathrm{m}$ filters) were incubated at 4 temperatures from 6 to $22^{\circ} \mathrm{C}$ either without any added nutrients or with added phosphorus, nitrogen and glucose. At all temperatures, the addition of nutrients produced a significant increase in bacterial growth rate (Table 4). However, temperature again had no significant effect on growth rate, irrespective of the nutrient status of the samples.

Table 3. Summary of seasonal changes in the growth response of Loch Ness bacterioplankton to addition of nutrients or to incubation at the annual maximum loch temperature. Values shown (nd = not determined) are growth rates in treatments as percent of growth rate in the control treatment incubated without nutrient addition and at the in situ loch temperature, with the statistical significance $(t$-test) indicated as: $" p<0.05 ; " \cdot p<0.01 ; \cdots p<0.001$

\begin{tabular}{|c|c|c|c|c|c|}
\hline Month & $P$ & $N$ & $\mathrm{C}$ & $\mathrm{P}+\mathrm{N}+\mathrm{C}$ & Temperature \\
\hline February & 144 & 78 & 141 & nd & 70 \\
\hline March & $171^{\bullet}$ & $171^{\circ}$ & $329 \cdots$ & nd & 43 \\
\hline April & 20 & 80 & 20 & nd & 20 \\
\hline May & 144 & 156 & 156 & $275^{\cdots}$ & $219^{\circ}$ \\
\hline July & $142 \cdot \cdot$ & 86 & 101 & $167^{\circ}$ & 98 \\
\hline August & $172 \cdots$ & 61 & 144 & $294^{\cdots}$ & 133 \\
\hline September & $144^{\circ}$ & 94 & $144^{\circ}$ & $194 \cdots$ & $194^{\cdots}$ \\
\hline October & 157 & 79 & $200^{\circ}$ & $307^{\circ}$ & 107 \\
\hline November & 100 & 98 & 74 & 88 & $64^{\circ}$ \\
\hline January & 87 & 54 & 74 & 146 & nd \\
\hline
\end{tabular}


Table 4. Bacterial apparent growth rates ( \pm SD) in February 1997 water samples from Loch Ness incubated at 4 temperatures without or with added nutrients $(P+N+C$, see text for details). The temperature in the loch at the time of sampling was $6^{\circ} \mathrm{C}$. ND: not determined

\begin{tabular}{|ccc|}
\hline $\begin{array}{l}\text { Temperature } \\
\left({ }^{\circ} \mathrm{C}\right)\end{array}$ & $\begin{array}{c}\text { Growth rate }\left(\mathrm{d}^{-1}\right) \\
\text { Without added } \\
\text { nutrients }\end{array}$ & $\begin{array}{c}\text { With added } \\
\text { nutrients }\end{array}$ \\
\hline 6 & $0.43 \pm 0.05$ & $0.77 \pm 0.03$ \\
10 & $0.51 \pm 0.03$ & $0.78 \pm 0.02$ \\
15 & $0.46 \pm 0.10$ & $0.80 \pm 0.13$ \\
22 & $0.38 \pm 0.01$ & ND \\
& & \\
\hline
\end{tabular}

\section{DISCUSSION}

The dilution method was originally introduced by Landry \& Hassett (1982) to estimate the impact of grazing by microzooplankton on marine phytoplankton, but has since been applied more widely to estimate grazing impacts on plankton communities (e.g. Weisse 1988, 1990, Tranvik 1989). The method remains controversial because it depends on 3 basic assumptions which can be difficult to evaluate: (1) exponential cell growth; (2) a linear relationship between grazing and the dilution factor; (3) intrinsic (gross) growth independent of the dilution factor. Our preliminary trials confirmed that the first assumption was satisfied even during the rather long incubations necessary because of the low bacterial growth rates. The low bacterial

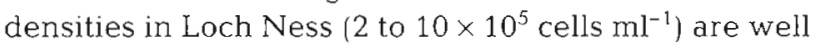
below those at which flagellate clearance rates start to become limited by the rate of phagocytosis (e.g. Fenchel 1982b), so the second assumption should also have been valid. The third assumption is more difficult to justify, since it could be argued that in more diluted samples cells would have both a higher initial resource availability per cell and a reduced regeneration of resources from the lower density of grazers. Since our preliminary trials showed that exponential growth was sustained through the incubation under all dilutions we feel that the iuid assumption probably was satisfied.

In principle, the intrinsic growth rates from our dilution experiments should be comparable to the growth rates measured in the (unenriched and undiluted) controls of our enrichment experiments, provided that the $1 \mu \mathrm{m}$ prefiltration removed all grazers from the latter The 2 separate measures of growth rates were actually significantly correlated $(r=0.814, p<0.001)$, although the intrinsic growth rates measured from the dilution experiments were mostly higher than the growth rates from the controls in the enrichment experiments. This difference may be attributable to incomplete removal of grazers by the $1 \mu \mathrm{m}$ prefilter producing residual grazing losses in the enrichment experiments; it is well known that $1 \mu \mathrm{m}$ filtration does not remove all HNF (e.g. Chrzanowski \& Simek 1993). Conversely, if higher resource availability in the more diluted samples did produce higher intrinsic growth rates, this would lead to slightly steeper regression slopes and, consequently, overestimates of both intrinsic growth rate and grazing rate. Any errors in this direction would actually strengthen our conclusions about the low rate of bacterial growth in Loch Ness and the relatively small impact of HNF grazing.

The bacterial intrinsic growth rates determined by the dilution technique for water samples from Loch Ness ranged from $0.687 \mathrm{~d}^{-1}$ down to not significantly different from zero (Table 2). These values are comparable with those reported for other freshwater and marine plankton (e.g. Tranvik 1989, Billen et al. 1990, White et al. 1991, Chrzanowski et al. 1995). That the maximum values recorded from Loch Ness are low compared with many maximum values reported from elsewhere is consistent with the view that bacterial growth rate reflects bacterial production, which tends to be lower in oligotrophic lakes like Loch Ness (Billen et al. 1990, Laybourn-Parry \& Walton 1998).

Variation through the year in the bacterial intrinsic growth rate in Loch Ness showed no evidence of a particular seasonal pattern (Fig. 2). At the start of the study, during the winter of 1996, the bacterial growth rate was very low, but the highest rates recorded during the study actually occurred in the following winter of 1997 . Low values actually occurred during the late summer when the phytoplankton biomass is maximal in Loch Ness (Jones et al. 1996). This is in marked contrast to other lakes (e.g. Lake Constance, Germany; Simon 1987, Güde 1990) in which bacterial abundance and production (and hence presumably growth rates also) show a pronounced seasonality, with low values during winter and high values during summer or associated with the spring phytoplankton bloom. The lack of such a pattern in Loch Ness suggests that bacterial growth is not principally determined by seasonal changes in insolation, either directly, by effects on temperature, or by dependence on DOC produced by phytoplankton

The deep mixing and poor light penetration into the moderately humic water mean that the underwater light climate experienced by the phytoplankton in the loch is exceptionally unfavourable, and the maximum daily rates of areal phytoplankton photosynthesis achieved in Loch Ness are only around $100 \mathrm{mg} \mathrm{C} \mathrm{m} \mathrm{Cm}^{-2}$ $\mathrm{d}^{-1}$ (Jones et al. 1996). This very low phytoplankton production in Loch Ness (Jones et al. 1996) is clearly insufficient to support the bacterial production (Laybourn-Parry et al. 1994), implying that bacteria in the 
loch are dependent on the influx of allochthonous DOC from the catchment. In practice, the total organic carbon content of the loch is dominated by detrital carbon of allochthonous origin (Jones et al. 1997). LaybournParry et al. (1994) suggested that this dependence of bacterioplankton in Loch Ness on allochthonous inputs of DOC would lead to fluctuations in bacterial growth and abundance being closely linked to patterns of rainfall and drainage from the catchment.

The period of our study actually coincided with an extended period of unusually low rainfall throughout much of the British Isles, including the Loch Ness catchment. The fluctuations in monthly rainfall at the loch (Fig. 5) do appear to link to the possible control of bacterial intrinsic growth rate by resource availability (Table 3). Prior to the start of the study, the rainfall during most of 1995 had been well below that of previous years. February 1996 was wetter, and at this time no nutrient limitation of bacterial growth was observed (Table 3). March was dry, and phosphorus, nitrogen and particularly organic carbon (as glucose) were each observed to stimulate bacterial growth. April and May were a little wetter and nutrient addition no longer stimulated bacterial growth. Through the summer months, when rainfall was low and the loch was stratified, phosphorus limitation of bacterial growth was consistently observed. October and November brought appreciable rainfall, and the associated flux of materials from the catchment into the loch appeared to remove mineral nutrient limitation of bacterioplankton, although organic carbon addition did produce a stimulation in September and October. Despite December 1996 and January 1997 being unusually dry months, bacterial growth in winter appeared to be unconstrained by nutrient availability. However, February 1997 was particularly wet but a combined PNC addition did stimulate bacterial growth (Table 4).

Overall this pattern of bacterial growth response to added nutrients in relation to rainfall patterns supports the view that bacterial growth in Loch Ness is mainly determined by the influx from the catchment by river discharge of both organic carbon substrates and mineral nutrients. A similar seasonal linkage between increased bacterial (and zooplankton) production and periods of snow-melt or rainfall was found in humic lake Kjesåsputten, Norway (Hessen 1998). In Loch Ness this relationship is unlikely to be precise, since the large volume of the loch and the relatively long water residence time will dampen the impact of discharge on concentrations of nutrients in the water column. The availability of nutrient resources relative to their stoichiometric requirement by bacterial cells is probably finely balanced in Loch Ness so that any one resource may appear as most limiting at different times. However, during the summer stratified period in

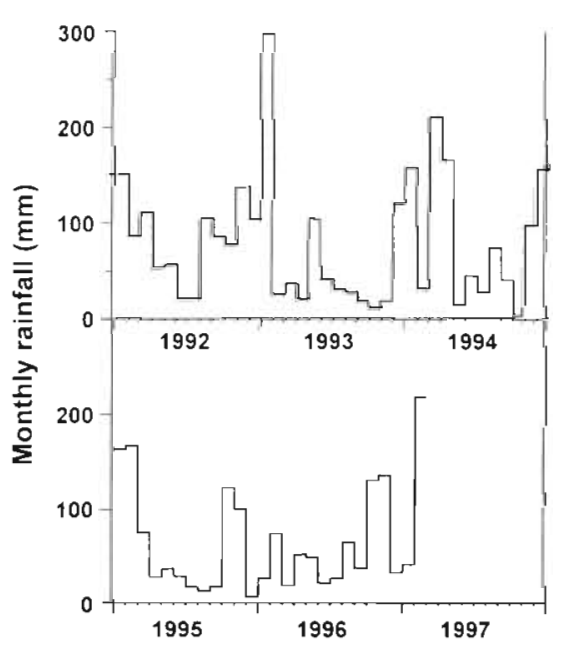

Fig. 5. Variation in total monthly rainfall measured in the grounds of Glen Urquhart High School, Drumnadrochit, by the northwest shore of Loch Ness

the loch, when phytoplankton production of organic carbon is highest and demand for nutrients within the epilimnion by phytoplankton is also maximal, availability of phosphorus is clearly the single most important factor determining bacterial intrinsic growth rate.

At times when resource availability appeared not to be limiting bacterial growth in Loch Ness, notably during the autumn and winter period of higher rainfall and more efficient circulation in the water column, it might be expected that bacterial growth rate would be temperature dependent. Such an effect was clearly reported from a eutrophic lake by Felip et al. (1996), and temperature has been shown to be a strong determinant of bacterial growth rates in freshwater and marine habitats (White et al. 1991). However, this was not evident in Loch Ness. Bacterial intrinsic growth rates determined from dilution experiments showed no significant regression on temperature ( $\mathrm{r}=0.232$ ). Moreover, during those periods when the ambient loch temperature was lowest, bacterial growth did not respond at all to higher temperature in experimental incubations, either in the monthly tests with the seasonal maximum loch temperature or in the more detailed test in February 1997. This was an unexpected finding and one which is difficult to explain, since bacterial intrinsic growth rate must be determined by either chemical or physical factors. Of course it is possible that some nutrient other than those tested was limiting bacterial growth, but in view of the abundant evidence for $\mathrm{P}$ and $\mathrm{N}$ limitation of planktonic processes this does not seem likely. It also seems unlikely that the forms in which the nutrient supplements were supplied (organic carbon as glucose, phosphorus as phosphate, nitrogen as ammonium) would have hindered 
their utilisation by the bacteria. One possible explanation is that the winter bacterial assemblage was adapted to lower temperatures and could not immediately respond to the much higher temperatures in the experiments. In the monthly tests (Table 3), bacterial growth rates at the higher incubation temperature were actually lower than at the control temperature in February, March, April and November 1996, although only in November was this reduction statistically significant. In addition, the February 1997 assemblage appeared to show an increased growth rate at $10^{\circ} \mathrm{C}$ compared to that at the in situ temperature of $6^{\circ} \mathrm{C}$, but growth rate declined at $15^{\circ} \mathrm{C}$ and declined further at $22^{\circ} \mathrm{C}$ (Table 4 ), although only the difference between the $10^{\circ} \mathrm{C}$ and $22^{\circ} \mathrm{C}$ treatments was statistically significant and when nutrients were added growth rate was constant at all temperatures.

Another possible explanation for the lack of an observed temperature response could be that the prefiltration through a $1 \mu \mathrm{m}$ pore size filter did not always remove all the grazers, and that in the higher temperature treatments any increased growth by bacteria was offset by increased grazing so that no significant difference in bacterial growth was observed between the treatments. This would be a particular problem if smaller flagellate cells were predominant in the community at lower lake temperatures. In fact, during incubations of samples from the winter of 1996/97, appreciable numbers of flagellates were noticed in some treatments despite $1 \mu \mathrm{m}$ prefiltration; no such growth of flagellates during the incubations was observed in any other experiments. Although we did not assess the size of HNF in our samples. Weisse \& Müller (1990) noted that small flagellates $(<2 \mu \mathrm{m})$ were numerically dominant in the HNF community of Lake Constance and, given the plasticity of many flagellates, it is quite possible that such cells might pass through the $1 \mu \mathrm{m}$ pores of the prefilter (e.g. Chrzanowski \& Simek 1993).

The estimated rate of grazing loss of bacteria varied through the study in a way that closely followed the variations in the bacterial intrinsic growth rate (Fig. 2). This suggests that bacterial production in Loch Ness is exploited rather efficiently by consumers. It has been argued that the heterotrophic nanoflagellates which are often presumed to be the principal consumers of planktonic bacteria require bacterial densities around $10^{6} \mathrm{ml}^{-1}$ in order to sustain their populations (e.g. Andersen \& Fenchel 1985). In Loch Ness, bacterial densities only rarely reached $10^{6} \mathrm{ml}^{-1}$ (Fig. 3). However, prey density thresholds for some flagellates as low as $2 \times 10^{4}$ bacteria $\mathrm{ml}^{-1}$, which are well below the bacterial densities in Loch Ness, have recently been reported from culture studies (Eccleston-Parry \& Leadbeater 1994). The density of HNF in the loch was also low compared to values commoniy reported from other lakes (e.g. Lake Constance; Weisse \& Müller 1990). However, the density of HNF relative to that of bacteria in Loch Ness was broadly consistent with the correlation for global freshwaters presented by Berninger et al. (1991). Assuming a typical clearance rate for HNF of $10 \mathrm{nl} \mathrm{cell}{ }^{-1} \mathrm{~h}^{-1}$ (Weisse 1990, Eccleston-Parry \& Leadbeater 1994), the initial HNF and bacterial abundances can be used to estimate the contribution of HNF to the grazing rate determined on each experimental occasion (Table 2). Such estimates range from 0 to $100 \%$ with a mean value for the 10 experiments of $26 \%$. Moreover, assuming the same typical clearance rate by

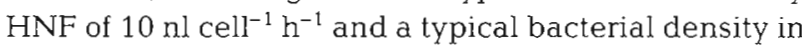
Loch Ness of $5 \times 10^{5} \mathrm{ml}^{-1}$ would allow a daily ingestion of 120 bacteria per flagellate. At a typical yield of $2 \times$ $10^{-3}$ flagellate cells per bacterium (Eccleston-Parry \& Leadbeater 1994), this would mean a flagellate growth rate of only $0.17 \mathrm{~d}^{-1}$. Such a growth rate is consistent with estimates from in situ incubations carried out in the loch previously (see Laybourn-Parry et al. 1994) and would be at the lower end of the range reported in the literature (Eccleston-Parry \& Leadbeater 1994). These simple calculations suggest that HNF have only limited impact on bacterial populations in Loch Ness, consistent with the findings of Laybourn-Parry \& Walton (1998).

In fact, grazing rates obtained from the dilution experiments were not correlated with HNF densities, so other groups of grazers must have been important bacterivores at times in Loch Ness. Mixotrophic flagellates are very scarce in the phytoplankton of Loch Ness (despite their frequent prevalence in the plankton of oligotrophic and dystrophic lakes). However, both ciliates (typically around 500 ind. $\mathrm{I}^{-1}$, mainly Strombidium viride and Halteria grandinella) and heliozoans (typically around 10 ind. $\mathrm{I}^{-1}$, mainly Actinosphaerium sp.) are present in the loch throughout the year without any marked seasonal pattern (Laybourn-Parry et al. 1994) and are likely to have been actively grazing bacteria in the dilution experiments. Rotifers (mainly Polyarthra spp. and Conochilus hippocrepis) are also an important component of the zooplankton community in Loch Ness during the spring and summer period, reaching densities of almost 200 ind. $1^{-1}$ (Fulcher 1996), and smaller types might have passed the $110 \mu \mathrm{m}$ prescreening mesh used to remove larger zooplankton prior to the dilution experiments. The cladoceran zooplankton which predominate in Loch Ness in late summer (Daphnia longispina and Bosmina coregoni) can also ingest bacteria but should have been effectively excluded from the dilution experiments by the prescreening. Thus any grazing by these cladocerans (as well as by larger rotifers and copepods) would be additional to the grazing rate measured in the dilution 
experiments. This additional, undetermined grazing pressure could, therefore, explain why net bacterial growth indicated by the dilution experiments did not always relate to observed fluctuations in bacterial density in the loch. A large population of $D$. Jongispina did develop in the loch during summer 1996, reaching a maximum recorded density of 6700 ind. $\mathrm{m}^{-2}$ in October (A. Shine pers. comm.). This might also partly account for the virtual disappearance of HNF in the summer, since these small flagellates would have been efficiently grazed by the filter feeding cladocerans (e.g. Sanders \& Porter 1990). Thus it appears that the grazing pressure on bacteria in Loch Ness derives from a diverse group of consumers (cf. Pace et al. 1990, Pace \& Cole 1994), in contrast to what appears to be the case in many other lakes in which grazing by HNF is the predominant cause of bacterial loss (Sanders et al. 1989, Tranvik 1989, Weisse 1990).

In conclusion, our results indicate that bacterial density in Loch Ness is rather low $\left(<10^{6}\right.$ cells $\left.\mathrm{ml}^{-1}\right)$ and exhibits the same limited annual variability that has been widely reported from other lakes. However, because the phytoplankton production in the loch is so low, bacterial growth rate does not show same the kind of marked seasonality that is commonly reported from temperate lakes. The low bacterial growth rates measured for Loch Ness (Table 2) and the frequent limitation of growth by 1 or more nutrients, particularly phosphorus (Table 3), show that bacterial growth in Loch Ness is mainly 'bottom-up' controlled by shortage of resources. There is also some evidence that bacterial growth is influenced by the influx of fresh resources from the catchment and hence by rainfall patterns. Although bacterial growth in Loch Ness is generally slow, new bacterial production is nevertheless removed quite efficiently by a variety of grazers so that bacterial densities show only little fluctuation. HNF are an important component of the bacterivore community at some times, but do not appear to have the overwhelmingly dominant role that they have been reported to play in other lakes.

Acknowledgements. We thank Adrian Shine and staff of the Loch Ness and Morar Project as well as colleagues from the Aquatic Sciences Research Group at Lancaster University for help with field sampling. We are grateful to Christine Briggs and the pupils of Glen Urquhart High School, Drumnadrochit, for supplying the rainfall data. This work was funded by Research Grant F/185/Y from The Leverhulme Trust.

\section{LITERATURE CITED}

Andersen P, Fenchel T (1985) Bacterivory by microheterotrophic flagellates in seawater samples. Limnol Oceanogr $30: 198-202$
Azam F, Fenchel T, Field JG, Gray JS, Meyer-Reil LA, Thingstad F (1983) The ecological role of water-column microbes in the sea. Mar Ecol Prog Ser 10:257-263

Bell RT, Vrede K, Stensdotter-Blomberg U, Blomqvist P (1993) Stimulation of the microbial food web in an oligotrophic, slightly acidified lake. Limnol Oceanogr 38:1532-1538

Berninger UG, Findlay BJ, Kuuppo-Leinikki P (1991) Protozoan control of bacterial abundances in freshwater. Limnol Oceanogr 36:139-147

Billen G, Servais P, Becquevort S (1990) Dynamics of bacterioplankton in oligotrophic and eutrophic aquatic environments: bottom-up or top-down control? Hydrobiologia $207: 37-42$

Bird DF, Kalff $J$ (1984) Empirical relationships between bacterial abundance and chlorophyll concentrations in fresh and marine waters. Can J Fish Aquat Sci 41:1015-1023

Børsheim KY (1984) Clearance rates of bacteria-sized particles by freshwater ciliates, measured with mono-disperse fluorescent latex beads. Oecologia 63:286-288

Caron DA (1983) Technique for enumeration of heterotrophic and phototrophic nanoplankton using epifluorescence microscopy and comparison with other procedures. Appl Environ Microbiol 46:496-498

Chrzanowski TH, Simek K (1993) Bacterial growth and losses due to bacterivory in a mesotrophic lake. J Plankton Res 15:771-785

Chrzanowski TH, Sterner RW, Elser JJ (1995) Nutrient enrichment and nutrient regeneration stimulate bacterioplankton growth. Microb Ecol 29:221-230

Cole JJ, Findlay S, Pace M (1988) Bacterial production in freshwater ecosystems: a cross-system overview. Mar Ecol Prog Ser 43:1-10

Coveney MF, Wetzel RG (1992) Effects of nutrients on specific growth rate of bacterioplankton in oligotrophic lake water cultures. Appl Environ Microbiol 58:150-156

Currie DJ, Kalff J (1984a) A comparison of the abilities of freshwater algae and bacteria to acquire and retain phosphorus. Limnol Oceanogr 29:298-310

Currie DJ, Kalff J (1984b) Can bacteria outcompete phytoplankton for phosphorus? A chemostat test. Microb Ecol 10:205-216

Ducklow HW, Kirchman DL, Quinby HL (1992) Bacterioplankton cell growth and macromolecular synthesis in seawater cultures during the North Atlantic spring phytoplankton bloom, May 1989. Microb Ecol 24:125-144

Ducklow HW, Purdie DA, Williams PJleB, Davies JM (1986) Bacterioplankton: a sink for carbon in a coastal marine plankton community. Science 232:865-867

Eccleston-Parry JD, Leadbeater BSC (1994) A comparison of the growth kinetics of six marine heterotrophic nanoflagellates fed with one bacterial species. Mar Ecol Prog Ser 105:167-177

Elser JJ, Stabler LB, Hassett RP (1995) Nutrient limitation of bacterial growth and bacterivory in lakes and oceans: a comparative study. Aquat Microb Ecol 9:105-110

Felip M, Pace ML, Cole JJ (1996) Regulation of planktonic bacterial growth rates: the effects of temperature and resources. Microb Ecol 31:15-28

Fenchel T (1982a) Ecology of heterotrophic microflagellates. IV. Quantitative occurrence and importance as bacterial consumers. Mar Ecol Prog Ser 9:225-231

Fenchel T (1982b) Ecology of heterotrophic microflagellates. II. Bioenergetics and growth. Mar Ecol Prog Ser 9:35-42

Fulcher AS (1996) The ecology of planktonic rotifers in two lakes of different trophic state. PhD thesis, Lancaster University

Gude $H$ (1986) Loss processes influencing growth of plank- 
tonic bacterial populations in Lake Constance. J Plankton Res 8:795-810

Güde H (1990) Bacterial production and the flow of organic matter in Lake Constance. In: Tilzer MM, Serruya C (eds) Large lakes: ecological structure and function. SpringerVerlag, Berlin, p 489-502

Hessen DO (1998) Food webs and carbon cycling in humic lakes. In: Hessen DO, Tranvik LJ (eds) Aquatic humic substances: ecology and biogeochemistry. Springer-Verlag, Berlin (in press)

Jones RI (1.992) The influence of humic substances on lacustrine planktonic food chains. Hydrobiologia 229:73-91

Jones RI. Laybourn-Parry J, Walton MC, Young JM (1997) The forms and distribution of carbon in a deep, oligotrophic lake (Loch Ness, Scotland). Verh Int Verein Limnol 26:330-334

Jones RI, Young JM, Hartley AM, Bailey-Watts AE (1996) Light limitation of phytoplankton in an oligotrophic lake - Loch Ness, Scotland. Freshwat Biol 35:533-543

Kankaala P (1988) The relative importance of algae and bacteria as food for Daphnia longispina (Cladocera) in a polyhumic lake. Freshwat Biol 19:285-296

Kepner RL, Pratt JR (1994) Use of fluorochromes for direct enumeration of total bacteria in environmental samples: past and present. Microbiol Rev 58:603-615

Landry MR, Hassett RP (1982) Estimating the grazing impact of marine micro-zooplankton. Mar Biol 67:283-288

Laybourn-Parry J, Walton M (1998) Seasonal heterotrophic flagellate and bacterial plankton dynamics in a large oligotrophic lake — Loch Ness, Scotland. Freshwat Biol 39:1-8

Laybourn-Parry J, Walton M, Young J, Jones RI, Shine A (1994) Protozooplankton and bacterioplankton in a large oligotrophic lake - Loch Ness, Scotland. J Plankton Res 16:1655-1670

Maitland PS (1981) The ecology of Scotland's largest lochs. Dr W Junk Publishers, The Hague

Marvalin O, Aleya L, Hartman HJ, Lazarek S (1989) Coupling of the seasonal patterns of bacterioplankton and phytoplankton in a eutrophic lake. Can J Microbiol 35:706-712

McQueen DJ, Post DJ, Mills RJ (1986) Trophic relations in freshwater pelagic ecosystems. Can J Fish Aquat Sci 43: 1571-1581

Pace ML (1988) Bacterial mortality and the fate of bacterial production. Hydrobiologia 159:41-50

Pace ML, Cole JJ (1994) Comparative and experimental approaches to top-down and bottom-up regulation of bacteria. Microb Ecol 28:181-193

Pace ML, McManus GB, Findlay SEG (1990) Planktonic community structure determines the fate of bacterial production in a temperate lake. Limnol Oceanogr 35:795-808

Editorial responsibility: Karel Šmek,

České Budějovice, Czech Republic
Pomeroy LR (1974) The ocean's food web: a changing paradigm. BioScl 24:499-504

Robarts RD, Wicks RJ (1990) Heterotrophic bacterial production and its dependence on autotrophic production in a hypertrophic African reservoir. Can J Fish Aquat Sci 47: $1027-1036$

Sanders RW, Caron D, Berninger UG (1992) Relationships between bacteria and heterotrophic nanoplankton in marine and fresh waters: an inter-ecosystem comparison. Mar Ecol Prog Ser 86:1-14

Sanders RW, Porter KG (1990) Bacterivorous flagellates as food resources for the freshwater crustacean zooplankter Daphnia ambigua. Limnol Oceanogr 35:188-191

Sanders RW, Porter KG, Bennett SJ, DeBaise AE (1989) Seasonal patterns of bacterivory by flagellates, ciliates rotifers and cladocerans in a freshwater planktonic community. Limnol Oceanogr 34:673-687

Sieburth JM, Davies PG (1982) The role of heterotrophic nanoplankton in the grazing and nurturing of planktonic bacteria in the Sargasso and Caribbean Seas. Annls Inst Oceanogr Paris 58(s):285-296

Simon M (1987) Biomass and production of small and large free-living and attached bacteria in Lake Constance. Limnol Oceanogr 32:591-607

Toolan T, Wehr JD, Findlay S (1991) Inorganic phosphorus stimulation of bacterioplankton production in a mesoeutrophic lake. Appl Environ Microbiol 57:2074-2078

Tranvik LJ (1989) Bacterioplankton growth, grazing mortality and quantitative relationship to primary production in a humic and a clearwater lake. J Plankton Res 11:985-1000

Vadstein O, Jensen A, Olsen Y, Reinertson H (1988) Growth and phosphorus status of limnetic phytoplankton and bacteria. Limnol Oceanogr 33:489-503

Wang L, Miller TD, Priscu JC (1992) Bacterioplankton nutrient deficiency in a eutrophic lake. Arch Hydrobiol 125 $423-439$

Weisse $\mathrm{T}$ (1988) Dynamics of autotrophic picoplankton in Lake Constance. J Plankton Res 10:1179-1188

Weisse I (1990) Trophic interactions among heterotrophic microplankton, nanoplankton, and bacteria in Lake Constance. Hydrobiologia 191:111-122

Weisse T, Müller $H$ (1990) Significance of heterotrophic nanoflagellates and ciliates in large lakes: evidence from Lake Constance. In: Tilzer MM, Serruya C (eds) Large lakes: ecological structure and function. Springer-Verlag. Berlin, p 540-555

White PA, Kalff J, Rasmussen JB, Gasol JM (1991) The effect of temperature and algal biomass on bacterial production and specific growth rate in freshwater and marine habitats. Microb Ecol 21:99-118

Submitted: June 10, 1997; Accepted: December 20, 1997

Proofs received from author(s): March 23, 1998 